\title{
Uffe Andersen
}

\section{Introduktion til Radoje Domanovics "Vodja"}

En serbisk ven anbefalede mig at læse fortællingen "Vodja" - Føreren eller Lederen - af Radoje Domanovic. Domanovic er med sine allegoriske og til tider fantastiske fortællinger en af serbisk litteraturs mest elskede satirikere, og min ven mente, at netop "Vodja" kunne hjælpe mig til at forstå, hvorfor hun - som mange andre her i landet - opgiver at høre efter, når talen (på tv, i radioen eller i dagligdagen) glider over til at handle om politik. Og hvorfor hun mener, det også er helt unødvendigt at høre efter.

Som hun sagde, da jeg fortalte, jeg nu havde læst historien: "nå - og hvad nyt er der så sket siden?!”

Altså: det, der i dag sker i serbisk politik og det serbiske samfund, er ikke meget andet end en trist gentagelse af det mønster, Domanovic - der levede mellem 1873 og 1908 - allerede i sin historie om Føreren fra 1901 (to år før, den serbiske konge blev myrdet af sine egne vagter og erstattet af én fra det rivaliserende dynasti, som de sammensvorne mente ville føre landet ud af krisen) havde gennemskuet.

Et mønster - mener min bekendte - der siden kun er blevet gentaget, men til gengæld er blevet det i adskillige varianter; senest med Josip Broz Tito og Slobodan Miloševic, der begge var Førere, Folket besluttede at følge "gennem ild og vand", som det hedder i Domanovics fortælling.

Det serbiske samfund er dybt patriarkalsk, og man har - mener dets kritikere - en hang til at opgive at tænke selv og i stedet blot følge Føreren og Hans (netop hans) mindste vink og indfald. Man skal have en evne til at overbevise sig selv om, at Han kan 'frelse folket' fra den 'fortabelse', det (evt. tilskyndet af Ham) føler at være på vej ud i. I stedet sker det gerne, at Han fører 'folket' fra en vanskelig situation og direkte ud i katastrofen - hvilket netop kan ske, når Folket opgiver at forholde sig til verden: I stedet for med sin egen fornuft at vælge den bedste løsning holder man blikket hæftet på Føreren, idet man (i hvert fald i det ydre) begejstret - og med trusler og fornærmelser til alle, der ikke gør som en selv - følger i hælene på Ham. 
Også i dag består serbisk politisk liv stort set af den slags 'førere' - mener min antipolitiske bekendte - og den eneste grund til optimisme og til, at der lige for øjeblikket ikke sker de helt store katastrofer, er, at Folket for en tid ikke har kunnet blive enige om én enkelt at følge.

I sådanne fredelige perioder befinder landet sig til gengæld i næsten total lammelse. Efter flere års tøven - hvor man f.eks. var i tvivl om, hvilken nationalhymne der skulle spilles, hvis en serber gik hen og vandt en olympisk medalje, og hvor publikum ved bl.a. fodboldlandskampe piftede ad den spillede melodi, fordi den var det (gode) gamle Jugoslaviens - har man for nylig endelig fået vedtaget et flag og en nationalsang. Men:

- siden FN i 1999 overtog administrationen af Serbiens sydlige provins, Kosovo, har ingen anet, hvor Serbiens grænser går;

- indtil 21. maj 2006 vidste man heller ikke, om og i fald hvor meget man var i land med Montenegro, men efter 14 års overvejelser (i 1992 stemte et overvældende flertal for at blive sammen med Serbien) har montenegrinerne nu bestemt sig for at blive Europas nyeste land. Dvs. lige så nyt som Serbien dermed også er. Endnu er det uklart, hvordan man vil løse 'skilsmisseproblemer' som at dele den fælles ejendom, men sværere bliver det med det immaterielle habengut - f.eks. nationalhelte (der ofte er de samme og tit selv opfattede sig som montenegrinske serbere), sprog (taler serbere montenegrinsk eller montenegrinere serbisk?) og kirke (i Montenegro blev i 1991 oprettet en national kirke, der ikke er anerkendt af nogen, men hævder og reelt har myndighed over både bygninger og sjæle);

- med Montenegros selvstændighed bliver også Serbien selvstændigt - eller 'alene med sig selv', som nogle i stedet udtrykker det. For selvstændigheden opnår man nærmest modvilligt, og man bliver på den måde også næsten tvunget til at tænke over spørgsmål som ‘hvem er vi - og hvor skal vi nu gå hen?' Bl.a. har den tidligere kongefamilie tilbudt at lede landet ud af uføret, og et af regeringspartierne har i mange år indædt talt for samme løsning (og bl.a. nævnt Holland og Danmark som værdige forbilleder), som andre lige så indigneret modsætter sig. Bortset fra demokratiske betænkeligheder ved igen at gøre Serbien til et kongerige er en almindelig holdning, at "de kongelige har haft chancen - og det gik jo ikke alt for godt";

- mens Jugoslavien oprindeligt ikke var serbernes idé eller kop te (men kroaternes og slovenernes, fordi de efter 1 . Verdenskrig i modsætning til serberne ikke kunne regne med at få tilkendt egne nationalstater), så lader det til, at flere serbere efter 2 . Verdenskrig identificerede sig med landet, end man generelt gjorde i flere af landets andre republikker. Blandt andet fordi mange hundrede tusinder etniske serbere levede uden for den serbiske republik. Også derfor hang serberne mere ved Jugoslavien, da andre i 1991 ville opløse landet - og derfor endte mange af dem ved Jugoslaviens forsvinden identitetsmæssigt i et tomrum; - er den nordlige provins, Vojvodina, ved at skille sig ud, eller får den bare autonomi - og i så fald hvor meget?; 
- to ud af tre serbere vil ind i EU, men for få måneder siden var det fire ud af fem. Mange tror ikke mere på, at EU overhovedet vil have dem med og mener, at hvis de opsporer og udleverer den krigsforbrydersigtede Ratko Mladic til domstolen i Haag, vil EU bare finde på en ny betingelse for at optage Serbien. Nogle mener, prisen for at blive medlem kan blive for høj, og f.eks. er Kosovo ikke til salg. En del ville heller ikke melde den bosnisk-serbiske ex-general Mladic, selv om de vidste, hvor han var. Ikke, at de bifalder de forbrydelser, han er sigtet for, men enten tror de simpelthen ikke på 'historien' om dem, eller også mener de, at den anden side i krigen begik lige så grove forbrydelser, som de ikke stilles til ansvar for. Denne blanding af stolthed og trods (og hos nogle ren og skær dumhed) låser forholdet til ikke bare EU, men også situationen i det serbiske samfund, hvor et flertal mener, EU er "eneste mulige vej frem";

- fra Miloševic blev væltet i 2000 var det politikernes væsentligste opgave at skaffe landet en ny, demokratisk forfatning, men i næsten seks år skete der ikke noget. Så gjorde partipolitiske finurligheder det pludselig "livsvigtigt for Serbien" at få sin forfatning, og man satte fuld damp på. Mange anså det for et umuligt projekt, da en tredjedel af parlamentsmedlemmerne er fra det ekstremt nationalistiske Serbiske Radikale Parti, da der skulle være to tredjedeles flertal i parlamentet, og mindst halvdelen af vælgerne bagefter skulle stemme for forslaget, og da albanerne i Kosovo ikke ville stemme om en serbisk forfatning, mens det serbiske parlament heller ikke ville skrive dem og Kosovo ud af forfatningen og dermed opgive den suverænitet over området, man siden 1999 har kæmpet så indædt for at holde fast i. Men 29. oktober vedtog serberne med nød og næppe ved en folkeafstemning en ny forfatning, "så vi nu kan komme videre", som politikere fra alle parlamentets partier siger. Men sammensætningen af parlamentet har gjort, at den nye forfatning også er kilde til ny splid. Blandt andet pga. måden, den med ét blev hastet igennem på - uden debat med borgerne - og fordi den nordlige provins, Vojvodina, ikke har fået den grad af selvstyre tilbage, som Miloševic tog fra den. Men mest sigende er måske forfatningens 'fortale', hvor provinsen Kosovo, der siden 1999 har været styret af FN, erklæres for at være en umistelig del af Serbien. Dén tilstand kommer fremtidige præsidenter også til at sværge på at ville forsvare "med alle midler" - men samtidig er ingen mere end serberne bevidste om, hvor sandsynligt det er, at 'det internationale samfund' meget snart tager Kosovo fra Serbien. Den nye forfatning kan altså ses som (endnu en) serbisk afvisning af at acceptere virkeligheden og udtryk for en stærk vilje og evne til selvforblændelse.

Osv. Alt det anede Radoje Domanovic jo nok ikke noget om - og det kan siges, at serberne gennem århundreder har vundet respekt og selvrespekt netop ved at nægte at acceptere enhver virkelighed, de har oplevet som ulidelig. Det kan også diskuteres, om serberne har mere hang til bevidstløst at følge end så mange andre. Men i hvert fald rammer Domanovic med sceneriet og med ordvekslingen, der afslutter "Vodja", meget præcist den aktuelle stemning i det, som i løbet af 1990'ernes første håndfuld år pludselig blev - og i et årti er forblevet - et af Europas fattigste lande: Serbien. 